\title{
SANTRI'S ECONOMIC EMPOWERMENT MODEL IN PESANTREN AL-ITTIFAQ CIWIDEY DISTRICT OF BANDUNG
}

\author{
Arip Syaprudin \\ STAI Darul Arqam (STAIDA) Garut \\ Email : arip.syaprudin@gmail.com
}

\begin{abstract}
Pesantren is a live episode that combines various life skills, not least agriculture. Various activities of life in pesantren have encouraged the sense of ideology of Santri. Educational activities that essentially the learning process requires thinking as a strong foundation so that the implementation of education that becomes the duty of his duties performed with a solid and really can be accounted for. This research uses descriptive qualitative, research place at Pesantren Al-Ittifaq Ciwidey district of Bandung. The subject of this research is Santri in pesantren while the informant is the Kiai or Ustādh. Data collection techniques use observation, interview, and documentation. I am checking the validity of the data using triangulation. Data analysis uses data reduction, data presentation, and conclusion. Based on the result of the research, it can be concluded that the model of empowering students at Pesantren Al-Ittifaq that is by the establishment of Core Management Unit Agribusiness, - effective practice in the field, establishing the Agribusiness Incubator Center, cooperating with various institutions and institutions, forming Santri agribusiness groups.
\end{abstract}

Keywords: Empowerment model, Santri, Pesantren (Islamic Boarding School)

\section{A. INTRODUCTION}

The ideas of the Santri Economic Empowerment Model (Pohl, 2009, p. 111) at Al-Ittifaq Ciwidey Islamic Boarding School in Bandung Regency (District of Bandung) born since 1970 by KH. Fuad Afandi (Fauroni, 2016). He tries to integrate religious activities with the agribusiness activities of Al-Itifaq Islamic Boarding School, following the natural potential around the pesantren. Agribusiness activities continue to this day, and even become the backbone of pesantren activities (Isbah, 2016, pp. 146-188).

The benefits felt by the Santri by participating in productive economic activities developed by Al-Itifaq Islamic Boarding School included among them the Santri no longer needed to expect deliveries from parents in the form of money, daily necessities and to buy notebooks and books - the book needed during education in the pesantren (Fuad, 2012). Because all the needs of the students during their stay at the Al-Ittifaq Islamic Boarding School have been fulfilled by the management of the cottage as part of the income generated by the Santri from their agribusiness activities (Noor, 2015).

Another benefit is that the Santri get two knowledge at once. Namely; firstly, obtaining religious knowledge which was obtained as the main objective of participating in the study at the Islamic boarding school, and secondly gaining valuable empirical experience in entrepreneurship for the future of the Santris themselves after later plunging into the broader community to empower the community (Maman \& Jahi, 2009). This article tries to explain the phenomena.

\section{B. METHOD}

This research uses descriptive qualitative, research place at Pesantren Al-Ittifaq Ciwidey district of Bandung. The subject of this research is Santri in pesantren while the informant is the Kiai or Ustadh. Data collection techniques use observation, interview, and documentation. The author has checked the validity of the data using triangulation. Data analysis uses data reduction, data presentation, and conclusion.

\section{RESULT AND DISCUSSION}

International Journal of Nusantara Islam Vol. 05 No. 02 2017: (213-222) DOI :10.15575/ijni.v5i2.4793 
The right learning process (model, method, material, location, and instructor that is right on target) can be a stimulus for achieving an increase in individual competence (Wachtel, 2012, p. 7). Kurt Lewin in Freeman argues that if the driving forces increase, because of the incentives that encourage changes in behavior (Freeman, 1999, p. 381). This stimulus is in the form of counseling or information related to the practice in question (Foddy, 1994, pp. 12-13). For example, a Santri who does not have agribusiness competencies can be increased by giving the driving force in the form of; training, guidance, and increasing the confidence of Santri. It is conducted by participating in managing the agribusiness owned by the pesantren; they can help each other between the pesantren and the Santri in terms of meeting the cost of education and living expenses as long as they become Santri. For this reason, the Santri was convinced of the importance of participating in managing the agribusiness business, so that the Santri wanted to change their behavior to succeed in their agribusiness efforts, for which he must be able to improve his ability in business (increasing competence).

In addition to creating students through the learning process in superior formal educational institutions, Islamic boarding schools also provide several other strategies, at least to introduce how modern society instruments itself to survive under the current globalization. Sonhadji Sholeh said that at least four attempts were being/going to Islamic boarding schools to equip their students. First, improve human resources. Second, improvements to the managerial system in Islamic boarding schools. Third, the economic independence of Islamic boarding schools. Fourth, the introduction and utilization of information technology (Sholeh, 2005, pp. 3-22).

So that in the subsequent development of the Santri, it needs to be given not only the sciences related to daily rituals that are practical and pragmatic but instead reasoning sciences that use revelation references. In this case, the capacity of the Kiai is a factor that determines the development of the curriculum. It is, of course, to improve the scientific quality of Santri boarding schools (Soebahar, 2013, p. 162). In this regard, Syeh Wahid Hasyim as the founding father of a new boarding school can take the idea that the students who study at the Islamic boarding school use more of the potential of their minds to solve social problems. Not just questions related to issues of religion, ritual, and worship but also real issues faced by Islamic societies, one of which is economic problems that are often a severe problem for Muslims. So, Santri must strengthen themselves with various kinds of expertise (Basori, 2006, p. 104).

Thus, it is necessary to design or format specific curriculum or scientific development and oriented on skills. In the context of the modernization era, the idea of updating the curriculum of Islamic boarding schools (Hwang, 2009, p. 70) has been actualized by Al-Ittifaq Islamic boarding schools. But there are still many other Islamic boarding schools that leave traditional curriculum system patterns without being offset by changes and demands of the modernization era (Hasyim, 2015). So, from there finally, was born a thought that almuhāfaz̧ah 'alā al-qadīm al-ṣalīḥ wa al-akhdh bi al-jadīd al-așlaḥ (al-Ba'sirwānī, 2016, p. 107) was still understood incompletely (Qomar, 2002, p. 194). Even though from the statement, it is clear that Muslims are encouraged to take something new, but do not leave the old ones while still being considered good (Effendi \& Suradi, 2014).

For this reason, the curriculum format that should be realized by Islamic boarding schools is a combination of the Salaf curriculum and the modern education system. It is hoped that the pesantren will be able to recognize cadres who are ready to fight in the era of modernization, namely candidates who are critical, creative and innovative as well as progressive and not conservative (Buang, 2008, pp. 321-341). So that students are ready whenever and wherever if needed by the community, and can move wherever he wants, meaning that it is not only co-opted in one space, namely space that is empty of civilization and glory (Saifuddin, 2015). While Haedari quoted by Basori said that as an educational institution, the pesantren teaching curriculum at least has an orientation to the current dynamics. It means that Islamic boarding school education institutions must further enhance the existing curriculum, in addition to the curriculum directed at religious seclusion, it should also include social and state material (Basori, 2006, p. 105).

To be more specific, ideally, the pesantren in the future must apply the sciences that are 'aqliyah, naqliyah

International Journal of Nusantara Islam Vol. 05 No. 02 2017: (213-222) DOI :10.15575/ijni.v5i2.4793 
and lisāniyah. The sciences of 'aqliyah are knowledge derived from the principles of human thought and research such as: exact science, biology, physics and science, while the naqliyah sciences are the sciences sourced from the Qur'ān and Hadīth, such as Tafsīr, Hadīth, Fiqh, Tawhīd, and so on. while the lisāniyah sciences are linguistics; such as Naḥw, Șarf, Mantiq, Balāghah, and so on (Suyatno, 2013).

Based on the description above, of course, it must be understood that scientific development or more specific curriculum development is a demand that is an essential agenda for the boarding school to reflect it with the era of "globalization" modernization. To design a pesantren-based curriculum, what needs to be considered is the principles of designing Islamic boarding schools. According to Halim, several principles need to be considered in preparing the relevant curriculum as follows (Sholeh, 2005, pp. 16-17): first, the philosophical basis of the State that takes place and directs the objectives of national education; second, the sociological basis concerning the state of society, the economy, customs, culture, health, and so on; third, the psychological basis that considers the factors contained in the education-training goals, for example, interests, needs, abilities, experiences, and so on; and fourth, the basis of the organization, where the curriculum is presented in certain forms both in terms of material, content, and sequence.

These principles are believed to be able to give birth to the formulation of curriculum objectives. The objectives of the pesantren curriculum are: first, general objectives, which are identical to the goals of national education; second, institutional objectives, namely the purposes of the institution or the boarding school concerned; third, curricular goals, namely the objectives of each field of study or subjects; and fourth, instructional objectives, namely specific goals that include knowledge, attitudes or skills that will be achieved by giving lectures related.

With the above formula, it can be concluded that to develop a relevant curriculum; pesantren must try to adapt the existing curriculum to the demands of changing times. Thus, the learning system, science, and curriculum in Islamic boarding schools will not be co-opted in the old paradigm of traditionalism. Based on this, to develop a pesantren curriculum, it must at least have a systematic step. Sulton mentioned several steps that must be taken in this matter, including (Fawait, 2013): (1) Conduct a study of needs (essential needs) to find out the determinants of the curriculum and its background. (2) Determine the subjects to be taught. (3) Formulate learning objectives. (4) Determine the Learning Outcomes expected from students in each item. (5) Formulate topics for each subject. (6) Determine the requirements demanded from students. (7) Determine the material that must be read by students. (8) Determine matching teaching strategies and provide teaching aids and teaching resources. (9) Determine the learning outcome evaluation tool and its rating scale. (10) Make a plan for the overall curriculum evaluation and its strategic needs.

The above explanation is a set of references that need to be implemented by Islamic boarding schools to develop their knowledge. So, it is clear that to improve the scientific "curriculum", which needs to be underlined is, a contextual review of the conditions and needs, and interests of the Santri. If the pesantren has conducted studies that are fundamental to these needs, then there are little alumni believe that the Islamic boarding school will be more qualified than the alumni of public education institutions. Even pesantren, whose influence has begun to be fragile and less attractive to the academic community, with the change will become an institution in the idol of society.

Combining modern and traditional scientific models seems to be the ideal reference for Islamic boarding schools. According to Abdurrahman Wahid, the importance of making curriculum models is to provide a minimum level of scientific knowledge of religion in Islamic boarding schools. With the achievement of these minimum levels, the pesantren concerned can incorporate elements of non-religious education into its curriculum, without endangering the preservation of the main tasks of the pesantren as bearers of the religious sciences which are based on the three forms of faith, Islam and devotion (Wahid, 2001, p. 121).

Some provisions must be made a limitation in the preparation of the intended curriculum models. First, the requirement to avoid repetition ('adam al tikrār). Insofar as it is not intended to be deepened (ta'ammuq) and penjosisi (tadarruj). Second, giving pressure to the exercises (tamrināt). Third, there is no avoidance of 
sequential leaps in the application of compulsory books (al-muqarrarah), during the education period from year to year. For example, from Al Jurumiyah in the first year, through Al-Imrithi in the second year, and ended with Alfiyah for nahwu in the third year (Wahid, 2001, p. 122).

A number of the pesantren's curriculums, then the pesantren need to acculturate and "naturalize" the pesantren with the development of the times of the community's needs. It needs to be done by entering general subjects that lead to the life skills of Santri boarding schools. The aim of developing pesantren is thus the integration between religious and non-religious knowledge so that the graduates produced will have a personality that is round and round, which combines in itself strong elements of faith and balanced mastery of knowledge (Wahid, 2001, p. 137).

The curriculum development program is intended, Islamic boarding schools will be able to print human beings who have a broad horizon of thought, a robust view of life, a practical approach and a multisectoral character in solving problems faced. Aside from the above ideas, there is also the importance of pesantren incorporate skills sciences that support the future of Santri. According to Haedari, the skills that can be applied in Islamic boarding schools can be in the form of farming skills, gardening, sewing, and even using craft skills. And this is adjusted to the background of the students (Haedari \& Saha, 2004, p. 85).

The provision of skills knowledge to Santri is undoubtedly a positive thing because it is an integration between the religious sciences which are held by Santri with skill skills for their future. The idea was long recommended by Mulyanto Sumardi (Sumardi, 1977, p. 44):

"The Ministry of Religion as the government agency responsible for fostering religious institutions, including Islamic boarding schools, has in recent years recommended Islamic boarding schools to provide religious education and also provide general knowledge, skills education, scouting, health, sports, and art education."

Muljanto Sumardi's report was found on the results of a seminar on Islamic boarding schools throughout Indonesia held at Sunan Kalijaga IAIN in July 1965 and educational seminars on religious schools which were carried out by the Department of Religion's increased research in June 1971 in Tugu-Bogor. Both of these seminars decided that in Islamic boarding schools, there should be an education in expertise such as carpentry, agriculture, curriculum reform, in addition to fostering personal, organizational, and administrative learning.

According to Mukti Ali, in the New Order period Islamic boarding schools have been launched with five educational components, namely: (a) Religious teaching and education, (b) Skills according to the abilities and needs of the surrounding community, (c) Scouting, where education and religious discipline can be carried out by scouting scout activities, (d) Health and sports. It needs to be reminded in Islamic Boarding Schools because it turns out there are still many Islamic boarding schools that take less attention to health and sports. (e) Islamic-based art (Ali, 1985, p. 21).

Based on the idea of applying these skills, pesantren will not only print students who are smart in the science of religion but allowing them also to be able to take part in the life of the community with the potential skills they have (Saepudin, 2016). From the above explanation, it is possible for pesantren to become educational institutions alternatives as what society aspires to. As well as carrying out its objectives following the mandate of the 1945 Constitution, namely to educate the nation's life in a sense, the pesantren, in this case, is not only a media that teaches doctrinal sciences but the sciences that are reasoning and skills. Because in essence, science is a tool in reaching the truth. It is following the opinion of Mastuhu, which explains the ultimate goal of science is to find the truth in this world and be able to improve the competence of human resources (Mastuhu, 2007, p. 154).

For Santri, to prepare themselves to be competent and capable of performing heavy tasks, namely facing the problems of the times, at least Santri must have five awareness, namely: (1) Spiritual awareness, this must 
be first and foremost instilled firmly, because this spiritual awareness is the basis and control of other consciousnesses. (2) Knowledge awareness, which is the awareness to know a tool to develop science to answer the challenges of the growing era. (3) Organizational Awareness, awareness of the importance of the organization as a vehicle for activities, and struggles that can deliver to goals effectively and efficiently. (4) Community awareness, awareness of living with others by realizing all the consequences. (5) Awareness of the nation and state, namely recognition of the importance of country and state and aware of all the implications (Ghazali, 2002, p. 51).

These five consciousnesses, if more summarized, will rely on two consciousnesses, namely: awareness of the position and function of self as a servant of Allah SWT according to his demands and the second is awareness of the situation and role of himself as the Khalifah of Allah on this earth. This awareness of position and function requires us to have a set of abilities so that we can well prosper the planet by bringing the most significant benefit to humans (Yuniarto, 2013, p. 54).

If this is the case, it is no exaggeration that we recognize that boarding education can create a generation of high integrity, is responsible for the knowledge it acquires, borrows the term pesantren "practice-knowledge and charitable deeds," aware of its creation as vicegerent on earth. It is, humans are made caliphs on earth and are tasked with prospering or building this earth. By the concept set by the commissioner, Allah, so that it will remain in the corridor of dedication to God in line to make humans and jinn the ultimate goal of life or the results of all activities as a dedication to God, the Creator (Philips, 1994, p. 225).

There are several fundamentals of Islamic boarding school education which have been rarely seen by those who consider themselves modern, including: (1) commitment to tafaqquh fĩ al-dinn, values to be firm towards the concepts and teachings of religion; (2) Education all the time (Full day school); (3) integrative education by collaborating between formal and non-formal education; (4) complete education, text and contextual or theoretical and practical; (5) there is diversity, freedom, independence and responsibility; and (6) in boarding schools are taught how to live in a community (Ismail, 2013).

After going through several periods of time, Islamic boarding schools grow and develop fertile and still bear their traditional characteristics even though there are still weaknesses that must be addressed. As an indigenous educational institution, according to Azra, Islamic boarding schools have a socio-historical root that is strong enough to make them able to occupy a relatively central position in the scientific world of their society while surviving amid a wave of change (Azra, 2001, p. 101).

So that in the face of the wave of change, Islamic boarding schools must be able to improve their human resources. In the context of increasing Human Resources (HR), M. Sulthon said that there were many Islamic boarding schools such as Gontor Ponorogo, Al Amin Sumenep, Darul Ulum Jombang, which adapted to the demands and needs of the community. Forms of activities carried out through pieces of training by inviting experts who have specific skills and skills (Sulthon, Khusnuridlo, \& Tasnim, 2002, p. 27).

It indicates that the current Islamic boarding school is trying to provide supplies to the students to be able to compete with graduates from outside the pesantren. Based on the managerial side, many Islamic boarding schools that have changed from the traditional administrative paradigm that is centered on the figure of the Kiai, then turn to the administrators who are equipped with knowledge of administration and management. Mudjamil Qomar said "(indeed) most traditional Islamic boarding schools are managed based on tradition, not professionalism based on skills (skills), both human skills, conceptual skills, and integrated technology skills. As a result, there is no careful planning, good distribution of power and authority" (Qomar, 2007, p. 5). This assumption cannot be justified anymore. The reason is that almost all Islamic boarding schools in Indonesia are given to professional people.

Based on the economic independence side of the Islamic boarding school, this context is the most obvious thing in the pesantren world. Because the Islamic boarding school is indeed famous for two connotations in 
the field of social economy; first, Islamic boarding schools as an economic development institution for the community. Second, pesantren have their economic resources to manage and develop Islamic boarding schools. In the first connotation, Ali Aziz said that the role of the pesantren is to be a pioneer for the middleclass economy, which has less access among the government bureaucracy. According to him, boarding schools must have qualified human resources to be able to advocate for small and medium economists (Aziz, 2005 , p. 210). While the second connotation, namely pesantren to have independence is intended as an educational institution that does not depend on community and government assistance.

Al Ittifaq Ciwidey-Bandung Islamic Boarding School in addition to providing students with religious knowledge is also equipped with science and experience (empirical) in the field of practical, productive economics, including the science of business agribusiness (Muttaqin, 2016). The aim is as an effort to empower the Santri both in economic aspects (because the backgrounds of the Santri come from low-income families, duafa and orphans) and provide abilities in the form of specific competencies according to the interests, educational experience, and talents possessed by the Santri (Faisal, 2013). The strategy was developed by Al Ittifaq Islamic Boarding School in the development of its agribusiness business so that the goal was achieved where the company of Islamic boarding schools succeeded, on the other hand, agribusiness competencies were also possessed by the Santri, which was done by forming a model for developing Santri empowerment (Hadi, 2008).

The development model, namely: (1) the establishment of the Agribusiness Unit Core Management, (2) conducting practical training, (3) forming the Agribusiness Incubator Center (AIC), (4) conducting cooperation/partnership, and (5) forming groups Santri agribusiness work. This empowerment development model is a forum and means for the Santri learning process so that behavior changes occur, where at first the Santri did not have agribusiness competencies which could change to new behaviors that controlled the agribusiness competencies (Zulkifli, 2016, pp. 128-130).

The knowledge and skills acquired by the Santri came from the learning process in the form of training activities (integrating theory and practice) and intensive guidance from both religious teachers, field extension workers, and senior Santri (supervisors) as group leaders who were responsible for the ability of Santri to become business managers. Anyone who have adequate knowledge and skills and can manage the business until they succeed. Whereas the learning process that is applied is correct, namely through the adult learning model and field school with NPPU (natural, present, process, and use) learning methods. The training material was adjusted to the presence of Santri at that time, whether he was pursuing cultivation techniques, grading techniques, packaging techniques, marketing techniques, or agribusiness management. While the training instructors were taken from among the boarding schools themselves, consisting of the foremen/group leaders and field extension workers (Zulkifli, 2016, pp. 128-130).

The duration of training is adjusted to the level of ability of a Santri to absorb the knowledge and skills provided by his foremen as a guide. The level of education of farmers, both formal and non-formal, will influence the way of thinking applied to their farming, namely in the rationality of their efforts to utilize every available economic opportunity (Rustandi, 2010, p. 84).

The economic empowerment model of the Santriat the Al-Ittifaq Ciwidey Islamic Boarding School in Bandung Regency is the establishment of the Agribusiness Unit Core Management, namely the establishment of an organization outside the Al-Ittifaq Foundation which functions and acts as the manager of the agribusiness business. Conduct practical training directly in the field (place of agribusiness) and to integrate the balance of application between theory and practice. Establish an Agribusiness Incubator Center (AIC), which is a counseling unit that functions as a place for students who have not succeeded in achieving their agribusiness competencies specially forged to be able to follow the abilities of other students. Cooperate partnership with various institutions and agencies, the purpose of which is to obtain multiple accesses such as training, capital, business land, and marketing results. Establish Santri agribusiness groups, namely by forming small groups based on the location of land or types of business commodities managed by as many as ten people per 1 ha 
of agribusiness land led by a foreman (group leader) (Rustandi, 2010, p. 100).

The benefits for Al-Ittifaq Islamic Boarding School itself with the existence of productive economic business activities. It has been carried out have multiple effects on; (1) private boarding schools, namely the continuity of the education process in the boarding school. Aside from being a means to fulfill the needs of boarding schools, it can also reduce production costs so that the products produced can have a competitive and comparative advantage and become a laboratory for the development of independent souls and Santri entrepreneurs. It is following the educational goals expected by the Al-Ittifaq Islamic Boarding School, namely the printing of students who are noble, independent and entrepreneurial, and (2) external boarding schools, namely these activities also benefit and improve the welfare of the surrounding community. It is because businesses in the pesantren besides involving the Santri also include the local community, both in the production of a commodity and in the development of the Islamic Boarding School Cooperative and the Integrated Hall of the Bayt al-Māl wa al-Tamwīl (Podungge, 2014).

The agribusiness units currently carried out by Al-Itifaq Islamic Boarding School cover a variety of business fields, as follows (Rahman, 2016, p. 6-7):

1. The production process, in the form of;

a. Producing highland vegetables to meet the demands of traditional markets and modern markets and supermarkets. The number of commodities produced by Al-Ittifaq Islamic Boarding School is \pm 25 types of plants, including; beans, potatoes, scallions, tomatoes, curly chili, green chili, paprika, chicory, lime, white cabbage. Red cabbage, mint leaves, radishes, pumpkin parang, pumpkin shoots, peas, spring corn, double onions chives, pumpkin siam, daikon, celery, kidney beans, and beans, carrots, and others.

b. Developing livestock businesses, including; fattening cattle and sheep and nurturing the area.

c. Processing of vegetable products so that the commodity can be accepted by the supermarket by specific standards. Before being sent to the vegetable supermarkets, the processing is done first through several stages, namely; (1) sorting, (2) grading, (3) packing, (4) writing, and (5) labeling.

2. Marketing, the results of vegetable production from Al-Ittifaq Islamic Boarding School have been able to meet market-market demands such as;

a. Traditional markets, namely the Caringin Bandung Main Market

b. Modern markets, such as; Macro, diamond, Superindo

c. Supermarkets, such as; Hero Supermarket, Yogya, Giant.

d. Hotels

3. Making and developing essential ingredients for composting for organic fertilizer, which is ready to use. The essential elements are Natural Fermentation Microorganism (NFM). This NFM can ripen compost within one week and has also been widely traded with the NFM code. The manufacturing location (processing plant) of the NFM is located in Garut, West Java.

The agribusiness commodities in Al-Itifaq Islamic Boarding School and its surroundings are commodities according to market demand, both traditional markets, modern markets, and supermarkets. To guarantee the absence of complaints from partner parties due to the lack of supply and quality of supply under the standard, the Al-Itifaq Islamic Boarding School has made efforts to anticipate that the managed turnover of the agribusiness business will not stop (Rustandi, 2010, p. 80). These efforts are carried out in three ways, namely: (1) quality management, namely by always dealing with and refining quality, quantity, and continuity, (1) to ensure that there is no shortage and delay in supply by applying production tolerance of $20 \%$. It is to anticipate the existence of production disruptions due to unpredictable natural factors, and (3) tighten the supply of goods, this is important so that there will be no compulsion in the future with excess supply because it will result in complaints from supermarkets to Islamic Boarding Schools Al-Ittifaq. Other efforts to fulfill market demand have been mutually agreed upon in the MOU (work contract), namely by cooperating with farmer groups in the area of Alam Endah Village. The farmer groups are coordinated by the Cooperative 
Islamic Boarding School (Kopontren) Alif (Rustandi, 2010, p. 80).

The Santri in managing their agribusiness are under the guidance of clerics and clerics. The Al Ittifaq Ciwidey Ponpes Foundation Bandung to streamline the management of religious students who have formed units as support and container for agribusiness activities, these units are: (1) Core management of agribusiness units, (2) Agribusiness Incubator Center (AIC), (3) Training, (4) Cooperation and partnerships, and (5) working groups. This grouping is tailored to the interests, level of education, and special skills that Santri possesses (Rustandi, 2010, p. 80-81).

\section{CONCLUSION}

Al-Ittifaq Ciwidey Islamic Boarding School in Bandung Regency is an educational institution that has succeeded in building a model of empowering its students. Through the establishment of an organization outside the Foundation, the institution creates the partnership which functions and acts as an agribusiness channel. Conducts practical training directly in the field, and integrates theory and practice, assistance from senior students, cooperation with various outside business institutions to market their products.

\section{REFERENCES}

al-Ba sirwānī, A. al-'Abbās Z. M. (2016). Nukhbat al-Afkār. Dār al-Kutub al-'Ilmiyyah. Ali, A. M. (1985). Beberapa Persoalan Agama Dewasa Ini. Jakarta: Rajawali Pers.

Aziz, Moh. A. (2005). Pesantren dan Pengembangan Masyarakat. In A. Halim, Manajemen Pesantren. Yogyakarta: LKis.

Azra, A. (2001). Pendidikan Islam, Tradisi dan Modernisasi Menuju Milenium Baru. Jakarta: Kalimah.

Basori, R. (2006). The Founding Father Pesantren Modern Indonesia: Jejak Langkah K.H. A. Wahid Hasyim (Cet. 1). Retrieved from https://trove.nla.gov.au/version/39456228

Buang, S. (2008). In W. T. Pink \& G. W. Noblit (Eds.), International Handbook of Urban Education. Dordrecht: Springer Science \& Business Media.

Effendi, M., \& Suradi, S. (2014). TRANSFORMASI KURIKULUM PESANTREN: Telaah Pemikiran KH. MA. Sahal Mahfudh dan Nurcholish Madjid. Cendekia: Jurnal Kependidikan Dan Kemasyarakatan, 12(1), 15-32. https://doi.org/10.21154/cendekia.v12i1.361

Faisal, I. (2013). Role of Networking Among DKM in The Community (Optimization of Religion in Counseling \& Extension District Rancabali Bandung West Java). Jurnal Bimas Islam, 6(1), 121-141.

Fauroni, R. L. (2016). MODEL PEMBERDAYAAN EKONOMI ALA PESANTREN AL-ITTIFAQ RANCABALI KAB. BANDUNG. INFERENSI: Jurnal Penelitian Sosial Keagamaan, 5(1), 1-17. https://doi.org/10.18326/infsl3.v5i1.1-17

Fawait, A. (2013). Transformasi Pengembangan Tradisi Pondok Pesantren. Edu Islamika, 5(1), 93-122.

Foddy, W. (1994). Constructing Questions for Interviews and Questionnaires: Theory and Practice in Social Research. Cambridge: Cambridge University Press.

Freeman, R. M. (1999). Correctional Organization and Management: Public Policy Challenges, Behavior, and Structure. Woburn: Elsevier.

Fuad, N. (2012). PENDIDIKAN BERBASIS MASYARAKAT DI PONDOK PESANTREN. Jurnal Manajemen Pendidikan, 3(1), 399-409.

Ghazali, M. B. (2002). Pesantren Berwawasan Lingkungan. Jakarta: Prasasti.

Hadi, A. P. (2008). PEMANFAATAN KELEMBAGAAN PONDOK PESANTREN BAGI PENYULUHAN PERTANIAN DAN PENGEMBANGAN AGRIBISNIS. Retrieved from http://suniscome.50webs.com/data/download/014\%20Ponpes\%20Agribisnis.pdf

Haedari, M. A., \& Saha, M. I. el-. (2004). Panorama Pesantren dalam Cakrawala Modern. Jakarta: Diva Pustaka.

Hasyim, H. (2015). Transformasi Pendidikan Islam (Konteks Pendidikan Pondok Pesantren ). Jurnal Ta'lim Pendidikan Islam, 13(1), 57-77. 
Hwang, J. C. (2009). Peaceful Islamist Mobilization in the Muslim World: What Went Right. New York: Springer.

Isbah, M. F. (2016). Examining the Socio-Economic Role of Islamic Boarding Schools (Pesantren) in Indonesia (UNSW). Retrieved from http://unsworks.unsw.edu.au/fapi/datastream/unsworks:39636/SOURCE02

Ismail. (2013). MENGGAGAS PONDOK PESANTREN SEBAGAI LEMBAGA PENDIDIKAN ISLAM MASA DEPAN YANG MENCERAHKAN1. Jurnal Al-Ta'dib, 6(1), 100-112.

Maman, U., \& Jahi, A. (2009). Kompetensi Wirausaha Santri di Beberapa Pesantren di Jawa Barat dan Banten. Jurnal Penyuluhan, 5(1), 26-35. https://doi.org/10.25015/penyuluhan.v5i1.9789

Mastuhu. (2007). Sistem Pendidikan Nasional Visioner. Jakarta: Lentera Hati.

Muttaqin, R. (2016). KEMANDIRIAN DAN PEMBERDAYAAN EKONOMI BERBASIS PESANTREN (Studi atas Peran Pondok Pesantren Al-Ittifaq Kecamatan Rancabali Kabupaten Bandung terhadap Kemandirian Eknomi Santri dan Pemberdayaan Ekonomi Masyarakat Sekitarnya). JESI (Jurnal Ekonomi Syariah Indonesia), 1(2), 65-94. https://doi.org/10.21927/jesi.2011.1(2).65-94

Noor, A. H. (2015). PENDIDIKAN KECAKAPAN HIDUP (LIFE SKILL) DI PONDOK PESANTREN DALAM MENINGKATKAN KEMANDIRIAN SANTRI | Noor | EMPOWERMENT : Jurnal IImiah Program Studi Pendidikan Luar Sekolah. EMPOWERMENT : Jurnal IImiah Program Studi Pendidikan Luar Sekolah, 3(1), 1-31.

Philips, A. A. B. (1994). The Fundamentals of Tawheed (Islamic Monotheism). Riyadh: Islamic Books.

Podungge, R. (2014). Potensi BMT (Baitul Mal Wattamwil) Pesantren Guna Menggerakkan Ekonomi Syari'ah di Masyarakat. Al-Mizan, 10(1), 48-68.

Pohl, F. (2009). Islamic Education and the Public Sphere. Munster: Waxmann Verlag.

Qomar, M. (2002). Pesantren: Dari Transformasi Metodologi Menuju Demokratisasi Institusi. Jakarta: Erlangga.

Qomar, M. (2007). Manajemen Pendidikan Islam: Strategi Baru Pengelolaan Lembaga Pendidikan Islam. Jakarta: Erlangga.

Rahman, D. F. F. (2016). Efektivitas Bimbingan Keagamaan dalam Menumbuhkan Jiwa Entrepreneur Santri (Penelitian di Pondok Pesantren Al-Itifaq Rancabali Kabupaten Bandung) - Digital Library UIN Sunan Gunung Djati Bandung (UIN Sunan Gunung Djati). Retrieved from http://digilib.uinsgd.ac.id/4685/

Rustandi, Y. (2010). Identifikasi Perilaku Santri pada Pengembangan Kompetensi Agribisnis (Studi Pemberdayaan Santri Pondok Pesantren Al-Itifaq). UNS, Surakarta.

Saepudin, J. (2016). PENDIDIKAN KECAKAPAN HIDUP DI PESANTREN DARUL HIKAM BANJARAN BANDUNG. EDUKASI: Jurnal Penelitian Pendidikan Agama dan Keagamaan, 14(1), 41-58. https://doi.org/10.32729/edukasi.v14i1.5

Saifuddin, A. (2015). EKSISTENSI KURIKULUM PESANTREN DAN KEBIJAKAN PENDIDIKAN. Jurnal Pendidikan Agama Islam (Journal of Islamic Education Studies), 3(1), 207-234. https://doi.org/10.15642/jpai.2015.3.1.207-234

Sholeh, S. (2005). Konsep-konsep Pengembangan Pondok. In A. Halim, Manajemen Pesantren. Yogyakarta: Pustaka Pesantren.

Soebahar, P. D. A. H. (2013). Modernisasi Pesantren: Transformasi Kepemimpinan Kiai dan Sistem Pendidikan Pesantren. Yogyakarta: Lkis Pelangi Aksara.

Sulthon, M., Khusnuridlo, M., \& Tasnim, Z. (2002). Manajemen Pondok Pesantren dalam Perspektif Global. Surabaya: LaksBang PRESSindo.

Sumardi, M. (1977). Sejarah singkat pendidikan Islam di Indonesia, 1945-1975. Jakarta: Lembaga Penelitian IImu Agama dan Kemasyarakatan (LPIAK), Badan Penelitian dan Pengembangan Agama, Departemen Agama.

Suyatno. (2013). View of Sekolah Islam terpadu; Filsafat, ideologi, dan tren baru pendidikan Islam di Indonesia. Jurnal Pendidikan Islam, II(2), 355-377.

Wachtel, B. (2012). Does pupil use of ICT increase attainment in MFL? München: GRIN Verlag. 
Wahid, A. (2001). Menggerakkan Tradisi: Esai-esai Pesantren. Yogyakarta: LKis.

Yuniarto, B. (2013). Membangun Kesadaran Warga Negara Dalam Pelestarian Lingkungan. Yogyakarta: Deepublish.

Zulkifli. (2016). PENGUATAN ECONOMIC CIVIC DALAM MEMBENTUK KEMANDIRIAN SANTRI SEBAGAI WUJUD GOOD GOVERNANCE : Studi Kasus Pondok Pesantren Al-Ittifaq Kecamatan Rancabali Kabupaten Bandung (UPI). Retrieved from http://repository.upi.edu/25826/ 